\title{
Speech and Politeness Disclosure Take Repentence in the Interaction of Students-Teacher
}

\author{
FX Sumarna \\ Descriptive Linguistics Study Program \\ Postgraduate Program \\ Universitas Sebelas Maret \\ Surakarta, Indonesia \\ sumarnafransiscus@gmail.com \\ Riyadi Santosa \\ Postgraduate Program, \\ Universitas Sebelas Maret \\ Surakarta, Indonesia \\ riyadisantosa@staff.uns.ac.id
}

\author{
Sumarlam \\ Postgraduate Program, \\ Universitas Sebelas Maret \\ Surakarta, Indonesia \\ sumarlam@staff.uns.ac.id \\ Wakit Abdullah \\ Postgraduate Program, \\ Universitas Sebelas Maret \\ Surakarta, Indonesia \\ abdullahwakit@yahoo.com
}

\begin{abstract}
This study aims to describe the form and function of speech acts values in student-teacher communication, both in the classroom when the learning activities take place or in the school environment that is outside the classroom. This research was conducted by using qualitative descriptive approach. From this research activity managed to find the form of values of speech acts in the communication in the school environment and in the learning activities in the form of acute speech acts that include assertive, expressive and commissive speech for students against the teacher. While the functions of followup actions such as a deterrent: The statement of error as an explanation, regret that can attract a sense of concern. refines communication in the form of an apology, and gives strength and encouragement to respect.
\end{abstract}

Keywords - speech acts; learning activities; classroom

\section{INTRODUCTION}

The language of life in society speaks and is used by its owners to establish a partnership in everyday life, including in any communication. In this study will be studied through ongoing teacher-student communication in the school environment. The focus of the assessment is to describe the teacher-affidavit in the classroom and formal forums, as well as in social interactions around the school. Language influenced by the dynamics or habits undertaken as participants speak in the speech community culture (speech community) concerned. In this study, the study of language life is a deterrent that occurs in the student-teacher communication in school and its environment. In turn, the social and cultural values of life and development contribute to the realization of the forms of language itself, as well as the selection of codes and politeness in the act of deterrent.

Speech Act is a functional unit in communicating. Speech produced is very dependent on the purpose or direction of speech. As the direction of the detective speech delivered by students to teachers in the school environment. Thus, the act of speech must be adapted to the speech situation. The situation of speech is a very actual social situation because it occurs in a wide society and in different circumstances. In such situations, there are rules of action that govern the actions of speakers and speech partners, the use of language, and interpretations of the actions and speech of speech partners. Speakers and speech partners in each speech Act must be responsible for real action and even the occurrence of irregularities about the rules of language in the interaction of language communication.

Language is a sign or symbol system that is expressing the cultural and social values and norms of a particular society in a social process of language (Santoso, 2003, p. 6). This means that every language can not be separated from its culture, that two different cultures will interpret the same utterance differently. Language is therefore used in different ways in different speaking societies. Besides being seen from the point of social semiotics, language can also be seen from the linguistic angle of anthropology which states that language is one of the thousands of oral communication used by different groups of people (Salzman, 1998, p. 46). This means that in the world there are thousands of groups of speakers of language and each group of speakers has their own language.

Wardhaugh (1987, p. 267) argues that language politeness is a language behavior that takes into account solidarity, power, intimacy, relationship status among participants, and rewards. Language politeness is also determined by awareness of social habits. True and need to be understood, that language shows a reflection of a person's person. A person's character, character, or person can be identified by the words he or she speaks. The use of polite, polite, systematic, orderly, clear, and straightforward language must reflect the person of a virtuous speaker. On the contrary, through the use of sarcasmic language, blasphemy, cursing, defaming, discrediting, 
provoking, mocking or harassing, is a private image that is virtuous and is clearly not commendable.

As politeness has been put forward by Leech (1993, pp. 327-329), managed to classify the act of speech into six kinds, namely assertive speech acts, representative, directive, expressive, commissive, and declaration. In this research, it is reasonable to study politeness that focuses on acer speech acts, expressive, directive, and commissive because to see the phenomenon that occurs in (Repentence), basically this is the most dominant act of speech in everyday activities that usually interact with people other. In addition, of course, this speech acts require the response of the opponent of speech both verbally and non-verbally. This is in line with the theory put forward by Searle. An example; Searle (in Gunarwan, 2007, pp. 85-86) one of them says that the act of speech directive is a speech act done by the speaker with the intention that the listener perform the actions mentioned in the speech, for example enjoining, pleading, appealing, and suggesting. In this research, concerning the process of repentence kind of speech acknowledgment will always invite the responsi of speech partner

Language politeness is one aspect that needs to be considered in communication. Whether or not a piece of speech depends on the size of the language speakers. Speech in Bahasa Indonesia in general is considered polite if speakers use polite words, the utterance does not contain direct mockery, not direct rule, and respect for others. Language politeness, especially in verbal communication can be seen from several indicators. One of them is the maxim of politeness in the speech. The more fulfillment of the maxims of politeness of a speech, the more polite the speech. Acting speech is one of the functional activities of human beings as an speaking creature.

Leech (1993, p. 9) suggests that pragmatics is the study of meaning in relation to situational situations (speech situations). Pragmatics are needed by analyzing a meaning spoken between speakers adapted to speech situations. Therefore, pragmatics is a branch of linguistics that studies the meaning of speech speakers in certain situations. This study examines the acts of assertive, expressive, and commissive speech in student-teacher focus in junior high school.

The reason for taking the object of research in the junior high school students' misfortunes is the fulfillment of the research data, the occurrence of Speech Act in the school environment. In the life of the general public, communication with speech acts (Speech Act) about the hardship is a thing that has been common in the culture of culture. However, the focus of this research is student-teacher communication in junior high. Researchers are more focused on the students' speeches, both in the classroom learning process, the official forums, and in the social interactions within the school environment, ie, student-teacher outbursts by connecting assertive, expressive, and commissive speech form, with a strategy of politeness in the focus of student-teacher persecution. Research on politeness in question, both the realization of the speech of the violence that occurred in Junior High School 1 Berbah and that occurred in Junior High School 2 Mlati Sleman Province Special Region of Yogyakarta.

Related to that, Austin (1965) states that the language is not just saying something (saying something) but also doing something else (doing something), ie the speaker wants to convey certain intentions to his partner. Searle in Asim Gunawan (2007, pp. 11-12), grouping speech acts into 5 types based on speaker's purpose, ie directive, expressive, commissive, declarative and representative (assertive). This research focuses on the theme of the crime in which the acts of assertive, expressive, directive, and commissive speech are contained. Likewise, this research also indicated the deterrent intention as a marker. In the assault as new findings are illustrated by the emergence of illoccusions with various categories of speeches among others; declare, regret, plead, and promise. The act of saying that it can be classified in a speech act which he called assertive acting (assertive speech act). The act of regret speech is classified in a speech act which he calls with expressive politeness (Expressive speech act). Speech begs to be classified in a speech act which is also called speech acts in expressive manner (Expressive speech act). Speech acts promised classified in acts of speech which he called with komisif komisif (commissive speech act). These four types of speech acts are examined in research ferries of violence used in communication learning in the classroom and official forums as well as in the communication of social interaction in the school environment.

Other factors, the context also includes one of the causes of language politeness, thus need to be considered. The formal atmosphere as the learning process or the official forum strongly emphasizes the existence of language assistance for the wearer. In a society generally a person is no longer viewed as an individual, but is seen as a member of a social group. Therefore, language and its users are not observed individually, but are always associated with activities in society (Lubis 1993, p. 124). Likewise with the phenomenon of speech of the students' disadvantage as a language marker, has been attached and entrenched in Junior High School 1 Berbah and in Junior High School 2 Mlati Sleman Province Special Region of Yogyakarta.

\section{RESEARCH METHODS}

This research is included descriptive qualitative research type because it aims to describe or describe in detail and depth about the deterrent and its function as a means of social control in the student-teacher interaction habits in the school environment today. According to Mc Millan \& Schumacher (in Syamsuddin and Damaryanti, 2006, p. 73) qualitative research is an approach which is also called investigative approach because researchers usually collect data with face-toface directly and interact with people who are in place of research. The research method is knowledge of various methods of doing research in an effort to obtain data that objectively until analyzing. This qualitative method is used because the emphasized in this study is a description of the 
process of why and how the act of spoken expression is expressed, which leads to an understanding of meaning. According Sudaryanto (1993, p. 9) research method is a procedure that must be taken in achieving a goal in conducting research.

\section{A. Technique of Data Collection}

In this study data collection is done by the method of referring note that is by listening at once do recording, observation and documentation. According to Mahsun (2012, p. 92) method is to get data that is done by listening about the use of language. This method has a basic technique in the form of tapping techniques. Techniques tapping is also called the basic technique in the method refer, because in essence the penyimakan can be realized by tapping. As is the meaning, research in the effort to obtain data is done by recording the use of language teachers and students are communicating in learning situations, formal forums, and social interactions in the school environment. In addition to the method refer, the study also uses documentation method. In this case, research is conducted by recording of learning activities and social interaction activities between teachers and students (the teacher is teaching and the students are studying in class, school activities, as well as in social interactions outside the classroom that are still within the school environment and or within one component of the school's residents, one object of this research, and / or specifically in the process of violence in the BK room. The object of the research is as well as the occurrence of speech acts (Speech Act) of teacher-students both in Junior High School 1 Berbah and Junior High School 2 Mlati, both are still in one region of Sleman Province Special Province of Yogyakarta (DIY).

\section{B. Technique of Data Analysis}

The analysis of the data also contains an understanding of the determination of lingual units based on certain theories and with the application of certain techniques (Sudaryanto, 1993, p.13). In this data analysis the author uses the method of extralingual. According to Mahsun (2012, p. 120) this method of extralingual matching is used to analyze elements that are extralingual, as well as connecting language problems with things that are outside the language.

The data required in this study is the occurrence of conversations from speakers and speech partners (Speech Act) which of course is more focused on teachers and students. Types of qualitative data in the form of words, phrases, sentences, and discourses, spoken by all or some residents in the neighborhood around the school which is the primary data because it is directly taken from the source. To reach for the sake of adequate analysis process of this research, required the data related to non-linguistic aspects especially text and context and understanding about cultural life of teacher and student in one component of research object.

\section{Techniques of Data Collection}

In this research, the researcher chooses the qualitative research type, the data obtained must be deep, clear and specific. In a Pragmatic linguistic study as a researcher, the method used in collecting data is commonly divided into two types: (1) Observation and (2) Elicitation. The method of observation is a method that is more concerned with the ethnographic approach and natural approach which often involves field notes and recording. Observation methods were chosen and used in data collection in this study, because the Oservation method has the advantage of obtaining data that is spontaneous, authentic and also has a high level of sufficiency. This approach comes from anthropology and focuses on the communication behavior of community members as school children naturally.

First: Sadap Technique. In this case, researchers directly perform data collection by tapping the occurrence of talks, both spoken word speakers and partners said that among other students-teachers in the State Junior High School 1 Berbah and in Secondary School (SMP) Negeri 2 Mlati Sleman.

Second: Technique Listen or what he calls SC technique is the technique of Listening (listening to teacher-student speech) and Record (doing recording according to the needs of research) which is an advanced technique of tapping techniques. The purpose of this activity is to record the occurrence of conversation between speakers and speech partners as student-teacher.

Third: Record Technique. Researchers do a direct recording of the dialogue of the nature or the emergence of natural conversations that occur between teachers and students. Recording can be done by using digital, camera, tablet, Aipet or Handycam, or even already enough with Mobile (HP) which also has been equipped with programming camera.

Fourth: Record Technique. Recording in this research can be done after technique of cognate technique of record and after recording done. After the recording on the data card can directly perform data classification or data collection on the data card. While the data card used is a data card as presented by Sudaryanto $(1988$, p. 6) can be; "Paper of any size and quality, important to be able to load, facilitate researchers in reading and also guaranteed durability".

Elicitation techniques can be differentiated into two subcategories (a) interviews and (b) Discorse Completion Tasks (DCT, Task Completing Discourse). Interviews in this study have been commonly done to the informants who determined with certain requirements in accordance with the interests of research. Interviews in this study were conducted individually, and also performed by grouping in the form of Focus Group Discussion (FGD). DCT is another way to encode data. ('Descriptive research is a description of the situation as it exists today. While analytical research uses facts or information that has been available, and this analysis to make a critical evaluation of the material.Hence, it can be concluded 
that descriptive analysis is done by describing and analyzing facts of research data. ')

\section{RESULT AND DISCUSSION}

The expected results of the research, besides revealing the form and strategy of politeness that emerged in the communication interaction of teachers and students. The form of the strategy in question is the emergence of a concept of student-teacher communication interaction in the school environment. The emergence of deterrent speech in the process of language learning, especially Indonesian language berperspektif pragmatik in secondary schools in Indonesia. The results of this study are expected to contribute in the development of linguistic and linguistic studies are polite berperspektif pragmatik and used as a reference for:

1. Unveil a new concept of the influence of a deterrent cultural background on the selection of politeness strategies in the student-teacher interaction domain in the school environment.

2. Develop curriculum in syllabus in junior high school, as well as its implementation in language learning process, especially Indonesian with pragmatic perspective in pragmatic in high school.

3. Develop language learning, especially the process of Indonesian violence that can integrate the elements of discourse competence, language competence, sociocultural competence, formulaic competence, interactional competence and strategic competence in the school environment.

4. Develop language learning, especially the context of speech disorder contained markers in Indonesian language-based character education, because politeness is full of absolute values with virtue in social interaction, especially in the school community.

The following is illustrated example of detective speech and civility categories that can be formulated from students' speech in the school environment, both in Junior High School 1 Berbah and in Junior High School 2 Mlati Sleman. The speech focus of the violence in the category of politeness that is; 1). Giving confession or wrong statement 'Yes I'm wrong sir' in the category assertive assertiveness, 2). Regret remorse for wrongdoing 'I am sorry for wrongdoing' in expressive civility category, 3). Apologies 'apologies for the mistakes I made' in the expressive politeness category, and 4). The minister promised not to repeat the wrongdoing that had been done 'I'm afraid Sir, and or I promise not to repeat this act of misconduct' in the category of commissary politeness.
The realization of a deterrent

TABLE I. DATA OBTAINED AT JUNIOR HIGH SCHOOL I BERBAH

\begin{tabular}{|c|c|c|c|}
\hline $\begin{array}{l}\text { No. } \\
\text { Data }\end{array}$ & Doer Speech & Speech Type & $\begin{array}{c}\text { Function } \\
\text { Tutorial }\end{array}$ \\
\hline \multirow[t]{6}{*}{$(1)$} & Teacher & $\begin{array}{l}\text { On Monday the Flag } \\
\text { Ceremony must be followed } \\
\text { by all school residents } \\
\text { wearing uniforms, students } \\
\text { wearing black shoes. }\end{array}$ & Rebellious \\
\hline & (1.a). Student & $\begin{array}{l}\text { Yes I am mistaken, do not } \\
\text { wear black shoes. }\end{array}$ & $\begin{array}{l}\text { Acknowledge } \\
\text { wrong }\end{array}$ \\
\hline & Teacher & $\begin{array}{l}\text { You feel wrong, then why not } \\
\text { wear black shoes? }\end{array}$ & Rebellious \\
\hline & (1.b). Student & $\begin{array}{l}\text { I apologize for this mistake, I } \\
\text { was upset and forgot about } \\
\text { the color of shoes I need to } \\
\text { wear. }\end{array}$ & Apologize \\
\hline & Teacher & $\begin{array}{l}\text { Oh yes, do not repeat yes, } \\
\text { obey the rules and school } \\
\text { rules. }\end{array}$ & Forgiving \\
\hline & (1.c). Student & $\begin{array}{l}\text { I promise not to repeat this } \\
\text { mistake Mom. }\end{array}$ & Promise \\
\hline
\end{tabular}

Context: Discourse delivered by students to teachers Counseling Guidance (BK) who undergo the task to overcome the problems in the school environment.

Case Type: Not wearing the Black Shoes uniform in the Flag ceremony.

Data (1.a). Students conduct a tampering with the speech: "Yes I am mistaken, do not wear black shoes." Once understood and scrutinized in depth, the student tells the story of a mistake that has been done. The mistake made is not to wear black shoes, which means violating school rules. From the point of view of linguistic polliteness of the utterance which states to be false, or to claim that he is guilty is categorized as assertive assertiveness. Assertive assertiveness as Searle (1969) has pointed out in Levinson (1985, p. 240), language politeness is based on speech acting functions to bind speakers to the truth of propositions expressed eg expressing something. In this study meant to declare wrong or confess wrong.

Data (1.b). Students conduct a tampering with the speech: "Sorry for this mistake, I was out of the day and forgot about the color of shoes I have to wear." Once understood and studied in depth, the student told the message in the form of an apology to the partner said because of mistakes that have been he did. The mistake made is not wearing black shoes, caused by daylight, but it also forgot about what color shoes to wear, means violating school rules. From a linguistic perspective the sentence polliteness apologizing for the error, or apologizing for being guilty is categorized in a courtesy directive. The politeness of the directive as proposed by Searle (1969) in Levinson (1983, p. 240), language politeness is based on speech acts spoken by the speaker in order for the partner to say something mentioned in the speech, for example begging, ordering. In this research is intended to convey an application so that the opponent said or the partner said to forgive the mistake made. 
Data (1.c). Students conduct a tampering with the speech: "I promise not to repeat this mistake." After being understood and scrutinized in depth, the student tells the message with a promise to the partner he said, with the meaning of the speech will not do the same action with the wrong action have been done. So next always try to wear black shoes. The mistake made is not to wear black shoes, which means violating school rules. By looking at the linguistic angle of speech politeness that promises not to repeat the mistakes that occur, or that promises that he will not repeat about wrongdoing is classified in komisif politeness. Comparative commission as Searle (1969) has pointed out in Levinson (1983, p. 240), language politeness is based on speech acting functions to bind speakers to the truth of propositions expressed eg expressing a promise. In this study is intended to provide an offer in the form of a promise not to repeat the wrong actions that have been done.

TABLE II. DATA OBTAINED AT JUNIOR High SCHOOL I BERBAH

\begin{tabular}{|c|c|l|l|}
\hline $\begin{array}{c}\text { No. } \\
\text { Data }\end{array}$ & Doer Speech & \multicolumn{1}{|c|}{ Speech Type } & \multicolumn{1}{|c|}{$\begin{array}{c}\text { Function } \\
\text { Tutorial }\end{array}$} \\
\hline (2) & Teacher & $\begin{array}{l}\text { Hi Dika, you 'talk yourself' } \\
\text { (talk yourself) on! }\end{array}$ & Rebellious \\
\cline { 2 - 4 } & (2.a). Student & I was wrong Mom! & $\begin{array}{l}\text { Confessing } \\
\text { wrong }\end{array}$ \\
\cline { 2 - 5 } & Teacher & $\begin{array}{l}\text { You have to take good care of } \\
\text { every teacher explanation! }\end{array}$ & Recommend \\
\cline { 2 - 5 } & (2.b). Student & $\begin{array}{l}\text { Yes, please apologize for my } \\
\text { mistake. }\end{array}$ & Apologize \\
\cline { 2 - 5 } & Teacher & $\begin{array}{l}\text { Yes, you will lose yourself, } \\
\text { the science does not increase } \\
\text { and also disturb other friends } \\
\text { who should be serious !. }\end{array}$ & Criticize \\
\cline { 2 - 5 } & $\begin{array}{l}\text { I am repente Mom, tomorrow } \\
\text { will always pay attention to } \\
\text { Mother's Student } \\
\text { Thanks. }\end{array}$ & Promise \\
\hline
\end{tabular}

Context: Discourse delivered by students to Social Science teachers who are undergoing the task of educating and teaching in the classroom.

Case Type: Talk on your own when IPS is on the way.

Data (2.a). Students conduct a tampering with the speech: "I am indeed mistaken." After being understood and scrutinized in depth, the student tells the story about the mistake that has been made. The mistake is to speak for themselves or speak for themselves when the teacher explains the subject matter, which should pay attention to it well, meaning no respect for the teacher. With the above mentioned speech viewed from the linguistic angle of speech polliteness which states wrong, or that it is guilty is classified in assertive assertiveness. Assertive assertiveness as Searle (1969) has pointed out in Levinson (1983, p. 240), language politeness is based on speech acting functions to bind speakers to the truth of propositions expressed eg expressing something. In this study meant to declare wrong or confess wrong.

Data (2.b). Students conduct a thoroughness with the speech: "Yes, please apologize for my mistake." Once understood and scrutinized in depth, the student speaks to say the request, apology to the partner said because of mistakes that have been made. The mistake is to speak for themselves when the IPS is not paying much attention to the teacher's explanation, which means that the student does not respect the teacher. With the above speech viewed from a linguistic angle of speech polliteness who apologizes for the error, or apologies for being guilty is categorized in expressive politeness. Expressive politeness as proposed by Searle (1969) in Levinson (1983, p. 240), language courtesy is based on speech acts spoken by the speaker so that partners say something done in the utterance, for example begging, ordering. In this research is intended to convey an application so that the opponent said or the partner said to forgive the mistake made.

Data (2.c). Students conduct a tampering with the speech: "I kapok Bu, tomorrow will always pay attention to Mother's explanation. Thank you. "After being understood and scrutinized deeply, the student tells the message with the word kapok to his partner, that is to his teacher, with the meaning of the speech will not do the same actions with the wrong actions that have been done. The mistake made is to speak for themselves when the IPS empowerment, which further promises to always try to pay attention to the teacher's explanation. With the speech is viewed from the linguistic angle of speech polliteness that promises not to repeat the mistakes that occur, or that promises that he will not repeat is pertained in komisif politeness. Comparative commission as Searle (1969) has pointed out in Levinson (1983, p. 240), language politeness is based on speech acting functions to bind speakers to the truth of propositions expressed eg expressing a promise. In this study is intended to provide an offer in the form of a promise not to repeat the wrong actions that have been done.

TABLE III. DATA OBTAINED AT JUNIOR High SCHOOL 2 MLATI

\begin{tabular}{|c|c|c|c|}
\hline $\begin{array}{l}\text { No } \\
\text { Data }\end{array}$ & Doer Speech & Speech Type & $\begin{array}{c}\text { Function } \\
\text { Tutorial }\end{array}$ \\
\hline \multirow[t]{6}{*}{ (3) } & Teacher & $\begin{array}{l}\text { Inspiration, you become a } \\
\text { diligent student, honest, } \\
\text { responsible, do not like to lie, } \\
\text { deceive itself and your } \\
\text { parents! }\end{array}$ & Rebellious \\
\hline & (3.a). Student & I really regret for this cheat & $\begin{array}{l}\text { Regret the } \\
\text { error }\end{array}$ \\
\hline & Teacher & $\begin{array}{l}\text { Should, everyone who acts } \\
\text { wrong should be sorry, } \\
\text { including you. }\end{array}$ & Recommend \\
\hline & (3.b). Student & Yes sir, please forgive me & Apologize \\
\hline & Teacher & $\begin{array}{l}\text { Yes, even you must be } \\
\text { deterrent and do not cheat } \\
\text { again. }\end{array}$ & Flattering \\
\hline & (3.c). Student & $\begin{array}{l}\text { I promise not to repeat the act } \\
\text { of cheating again sir }\end{array}$ & Promise \\
\hline
\end{tabular}

Context: A deterrent taught by students to English teachers who are undergoing the task of educating and teaching in the classroom.

Case Type: Nyotek during repetition

Data (3.a). Students conduct a tampering with the speech: "I am really sorry for this cheat." After being deeply 
understood and scrutinized, the student repeatedly regretted the act, that is, as a result of the wrongdoing. The mistake made is a repeat nyotek. From the perspective of linguistic polliteness, the speech that regrets the mistakes made is by the 'regret' speech which is categorized in expressive civility category. Expressive politeness as Searle (Hindenlang, 2010, pp. 43-45) has put forward about expressive speech that serves to express sympathy is a speech to express sympathy, regret or sadness over something that happens. Although it is smaller in scale than the big calamity as a person's death. The sympathetic speech function consists of remorse, sympathy, compliments, condolences and grief. In this study, regret is done because of mistakes for students to the teacher.

Data (3.b). Students conduct a tampering with the speech: "Yes sir, my apologies" Once understood and scrutinized in depth, the student speaks to say the request, apologizing to the partner said because of mistakes that have been made. The mistake made is a repeat nyotek. With the above speech viewed from a linguistic angle of speech polliteness who apologizes for the error, or apologies for being guilty is categorized in expressive politeness. Expressive politeness as proposed by Searle (1969) in Levinson (1983, p. 240), language courtesy is based on speech acts spoken by the speaker so that partners say something done in the utterance, for example begging, ordering. In this research is intended to convey an application so that the opponent said or the partner said to forgive the mistake made.

Data (3.c). Students conduct a tampering with the speech: "I promise not to repeat the act of cheating again sir." Once understood and scrutinized in depth, it can be conveyed the intention that the students tell the message by marked a promise to the partner said, with the meaning of speech will not take action same as the mistake that has been done. It continues to always try to wear full uniforms at the flag ceremony on Monday. The mistake made is a repeat nyotek. Thus, from the point of view of linguistic polliteness, the speech 'promises' not to repeat the error, or promising that he will not repeat is classified in the category of commissive politeness. Commissive politeness as written by Searle (1969) in Levinson (1983, p. 240), language politeness is based on speech acting functions to bind speakers to the truth of propositions expressed eg expressing a promise. In this study is intended to provide an offer in the form of a promise not to repeat the wrong actions that have been done.
TABLE IV. DATA OBtained AT Junior High School 2 MLATI

\begin{tabular}{|c|c|l|l|}
\hline $\begin{array}{c}\text { No } \\
\text { Data }\end{array}$ & Doer Speech & \multicolumn{1}{|c|}{ Speech Type } & \multicolumn{1}{|c|}{$\begin{array}{c}\text { Function } \\
\text { Tutorial }\end{array}$} \\
\hline (4) & Teacher & $\begin{array}{l}\text { The school is where Risma is } \\
\text { studying, not a place to find } \\
\text { enemies to fight each other! }\end{array}$ & Rebellious \\
\cline { 2 - 4 } & (4.a). Student & I'm wrong Mom & $\begin{array}{l}\text { Confessing } \\
\text { wrong }\end{array}$ \\
\cline { 2 - 5 } & Teacher & $\begin{array}{l}\text { Fellow friends should keep } \\
\text { each other harmony, because } \\
\text { together with the purpose of } \\
\text { learning. }\end{array}$ & Criticize \\
\cline { 2 - 5 } & (4.b). Student & I apologize for my mistake & Apologize \\
\cline { 2 - 5 } & Teacher & $\begin{array}{l}\text { There thank, if you accept it } \\
\text { must be peaceful, and do not } \\
\text { be repeated again. }\end{array}$ & Recommend \\
\cline { 2 - 5 } & (4.c). Student & $\begin{array}{l}\text { I promise not to repeat this } \\
\text { mistake. }\end{array}$ & Promise \\
\hline
\end{tabular}

Context: Discourse delivered by students to science teachers who are undergoing the task of educating and teaching in the classroom.

Case Type: Fighting by hitting friends until sick

Data (4.a). Students conduct a tampering with the speech: "I'm mistaken." After being understood and scrutinized in depth, the student tells the story of a mistake that has been made. The mistake is to fight by hitting a friend until sick. From the point of view of linguistic polliteness, the utterance of misleading speech, or the confession that is guilty is classified as assertive assertiveness. Assertive assertiveness as Searle (1969) has pointed out in Levinson (1983, p. 240), language politeness is based on speech acting functions to bind speakers to the truth of propositions expressed eg expressing something. In this study meant to declare wrong or confess wrong.

Data (4.b). Students conduct a tampering with the speech: "Sorry for my mistake." After being understood and scrutinized in depth, the student spoke to say the apology to the partner, because the mistake had been made. The mistake is to fight by hitting a friend until sick. With the above speech viewed from a linguistic angle of speech polliteness who apologizes for the error, or apologies for being guilty is categorized in expressive politeness. Expressive politeness as proposed by Searle (1969) in Levinson (1983, p. 240), language courtesy is based on speech acts spoken by the speaker so that partners say something done in the utterance, for example begging, ordering. In this research is intended to convey an application so that the opponent said or the partner said to forgive the mistake made.

Data (4.c). Students conduct a tampering with the speech: "I promise not to repeat this misdemeanor." After being understood and scrutinized in depth, it can be conveyed that the student speaks the message by marking a promise to his partner, with the meaning of the speech will not take action same as the mistake that has been done. The mistake is to fight by hitting a friend until sick. Thus, when viewed from the linguistic point of politeness the word 'promised' not to repeat mistakes that occur, or promising that he will not repeat is 
classified in the category of commissary politeness. Commissive politeness as written by Searle (1969) in Levinson (1983, p. 240), language politeness is based on speech acting functions to bind speakers to the truth of propositions expressed eg expressing a promise. In this study is intended to provide an offer in the form of a promise not to repeat the wrong actions that have been done.

\section{CONCLUSION}

Based on the discussion, there are two conclusions of research results as follows: First With regard to the form of acts of detective speech in this study, as the researchers write there are 4 special categorical of which are: (a) statement to confess himself that has had various errors, (b) statement for self-regret, namely that revealed that by mistake the self-errors he has committed are always in his regret. (c) statements about apology or forgiveness. For the next (d) to the peak that will always be followed by mulculnya attitude to feel deterrent, by trying not to do it again for the wrong actions or wrongdoing with the motivated to tell the sermon.

Second Function of student action act is student-teacher communication interaction in school environment there are four types. The type of speech acting function is 1) the function of the student's error statement as an explanation of the teacher. 2) a regret function that can attract a sense of caring. 3) the function of refining communication in the form of an apology. 4) the function of strengthening and the spirit to respect. With the fulfillment of four types of speech acts thus presumably the display of teacher-language communication will appear to be more polite.

\section{SugGestions}

The expected result in this research is that it can be applied about students' habits of telling to the teacher. Similarly, they used to use a deterrent that works to increase the activity and passion and spirit of the students themselves in the interaction of communications in the school environment. This discourse is a cause or a way to give pleasure and concentration of learning situations undertaken by students in developing their competencies.

As a student who studies in school, should always be aware of the importance of communicating and receiving knowledge transfer from his teacher. With regard to this research, students should not be hesitant in giving a deterrent to mistakes to teachers. Just as students who are accustomed to doing smile, greetings and greetings, are thus able to create a cool and pleasing environment for the whole school community, especially especially for teachers. In this case it is also good to enact a deterrent culture among students it is learning. Thus creates a cooler atmosphere again based on the habit that is more polite. A sign of student appreciation of the teacher does not have to be material in the form of objects or gifts, but enough already with a deterrent that can be as a first step. Even can also be a variety of detective words from students who are all the fun of his teachers for example, respectful. With the appearance of acts of such a detective, presumably able to make students can get a great happiness. In addition, it is also possible about the attitude and psychology of students who can get coolness, comfort, create a polite culture to have a sense of in the smoothness of learning in the school environment more particularly follow all the learning that it must be received.

\section{Reference}

Austin, J.L. (1965). How to Do Things with Words. Cambridge: Harvard University Press.

Brown, P. \& Levinson, S. (1987): Politeness: Some Universals in Language Usage. Cambridge: Cambridge University Press.

Gunarwan, A.. (2007). Teori dan kajian nusantara. Jakarta: Universitas Atmajaya.

Leech G. (1993). Prinsip-prinsip Pragmatik. translator M.D.D Oka. Jakarta: Universitas Indonesia Press.

Levinson. S. C. (1985). Pragmatics. Cambridge: Cambridge University Press.

Lubis, H. H. (1993). Analisis Wacana Pragmatik. Bandung: Angkasa.

Mahsun (2012). Metode penelitian bahasa: Tahapan strategi, metode, dan tekniknya. Jakarta: PT Raja Grafindo Persada.

Moleong L.J. (2010). Metodologi penelitian kualitatif. Bandung: Remaja Rusda Karya.

Salzmann. Z. (1998). Language culture and society . An introduction to Llinguistic Anthropology. Colorado: Westview Press.

Santosa, A. (2003). Bahasa politik pasca orde baru . Jakarta: Penerbit Wedhatama Widya Sastra Jakarta.

Searle, J.R. (1979), Speech acts, London: Cambridge University Press.

Spradley, J.P. (1997). Metode Etnografi. (M. Y. Elisabeth, Trans.). Yogyakarta: PT Tiara Wacana Yogya.

Sudaryanto. (1988). Menguak fungsi hakiki bahasa. Yogyakarta: Duta Wacana University Press.

Sudaryanto. (1993). Metode dan aneka tehnik analisis bahasa (Pengantar penelitian wahana kebudayaan secara linguistik). Yogyakarta: Duta Wacana University Press.

Sugiyono (2009). Metode penelitian pendidikan (Pendekatan kuantitatif-kualitatif, dan $R \& D$. Bandung : Penerbit Alfabeta.

Syamsuddin, \& Damaianti, Vismaia S. (2006). Metode penelitian pendidikan bahasa. Bandung: PT Remaja Rosdakarya.

Wardhaugh, R. (1987). Introduction to Linguistics. Oxford: Blackwell Publishers. 